\title{
Effect of Glycine, Methionine and Tryptophan on the Vegetative Growth, Flowering and Corms Production of Gladiolus Plant \\ Mahmoud Khattab ${ }^{1}$, Ashraf Shehata ${ }^{1}$, Eman Abou El - Saadate ${ }^{2}$ and Khamis Al-Hasni ${ }^{1}$
}

\begin{abstract}
The present study was carried out during the year of 2015 at two different locations i.e. nurseries. The first location was at The Department of Floriculture, Ornamental Horticulture and Garden Design, Faculty of Agriculture, University of Alexandria at Shatby and the second location was at Montazah Research Branch, Horticulture Institute, Ministry of Agriculture, Alexandria Egypt, to investigate the effects of different concentrations of glycine (zero, 75, 225 and $450 \mathrm{ppm}$ ), methionine (zero, 150,300 and $600 \mathrm{ppm}$ ) and tryptophan (zero, 300,600 and $900 \mathrm{ppm}$ ) with two application methods (pre-soaking the corms for $24 \mathrm{~h}$ before planting, or foliar spraying three times at stages of formation of 2,4 , and 6 leaves) on the vegetative growth, flowering characteristics, corms production and some chemical analysis of Gladiolus grandiflours cv. "Rose Supreme " plants.

The corms of the used cultivars were planted on January 27, 2015 in $30 \mathrm{~cm}$ plastic pots filled with a mixture of sand and peat moss at the ratio of $4: 1$ by volume, respectively. All the normal culture practices of growing Gladiolus corms were applied as usual manner. The experiment layout was designed to provide complete randomized blocks containing four replicates, each replicate had 24 treatments and three corms were used for each treatment in each replicate (plot).

Results revealed that using the lowest concentration from any of the used amino acids (glycine at $75 \mathrm{ppm}$ or methionine at $150 \mathrm{ppm}$ or tryptophan at $300 \mathrm{ppm}$ ) regardless of the used application method (presoaking or foliar spraying) gave the highest significant increase in most of the studied parameters of gladiolus plant (vegetative growth, flower characteristics, corms and cormels production and some of the chemical analysis) compared with the control treatment. While, leaves number per plant and the time taken by flower buds to show their color did not significantly affect with the used amino acids concentrations and their application methods, compared with the control treatment.
\end{abstract}

Besides, using the highest concentration from any of the used amino acids (glycine at $450 \mathrm{ppm}$, or methionine at $600 \mathrm{ppm}$, or tryptophan at $900 \mathrm{ppm}$ ) gave the tallest spikes, compared with the other concentrations. The largest corms fresh weight was obtained by using glycine at $75 \mathrm{ppm}$, compared with the other treatments. Using methionine at $150 \mathrm{ppm}$ or $300 \mathrm{ppm}$, regardless of the used application method, gave the highest content of nitrogen and total carbohydrates content of the produced corms, respectively, compared with the other treatments.

From the previous results, it can be generally recommended treating Gladiolus grandiflorus cv. "Rose Supreme" with presoaking the corms for $24 \mathrm{~h}$ before planting in tryptophan solution at $300 \mathrm{ppm}$ or with 100 ppm three times as foliar spraying at formation of two, four, and six leaves to obtain the maximum improvement of the vegetative growth, flowering characteristics, corms and cormels production.

Key words: Gladiolus grandiflorus, amino acids.

\section{INTRODUCTION}

Gladiolus is known as a queen of the bulbous plants, which is valued for its beautiful flower spikes. Its cultivation is getting popular for its beautiful flowering spikes having a longer life as cut flower. Its magnificent inflorescence with variety of colours and number of pretty florets had made it attractive for diversified use in the garden. It is an important cut-flower in both domestic and international market.

Gladiolus is one of the few plants which produce pleasant cut flower with long spikes. These spikes are an integral part of almost every cut flower arrangement ranging from table decoration to bucket formation. The name Gladiolus was originally driven from a Latin word meaning a sword on account of the sword like shape of its foliage.

The flower quality and spike length of Gladiolus can be improved by adopting proper package of cultural practices, like timely planting, proper planting distances between rows and between plants, weeding and proper irrigation. Beside these cultural practices, application of plant nutrients can play a vital role to produce good quality flowers.

Research has demonstrated that plants can absorb and assimilate amino acids as well as $\mathrm{NO}_{3}{ }_{3}$ and $\mathrm{NH}_{4}{ }^{+}$as their main nitrogen sources (Parson et al. 2003).

Amino acids are particularly important for stimulating cell growth. They act as buffers which help to maintain a favorable $\mathrm{pH}$ value within the plant cell, since they contain both acid and basic groups, and they remove the ammonia from the cell. This function is associated with amide formation, so they protect the

${ }^{1}$ Fac.Agric. Alex.Uni. Depart. OF Flori.Ornam.Hort. and

Landscape Gardening.

${ }^{2}$ Hort.Res. Institute, Agric. Research Center, Montazah,

Alexandria, Egypt.

Received November 20, 2016, Accepted December 7, 2016 
plant from ammonia toxicity. Amino acids also inhibit plant nitrate uptake (Aslam et al. 2001). They can serve as a source of carbon and energy as well and protect the plant against pathogens. Amino acids have a function in the synthesis of amines, purines, and pyrimidines, alkaloids, vitamins, enzymes, terpenoides and others (Goss, 1973).

Amino acids are well known bio stimulant which have positive effects on plant growth, yield and significantly mitigates the injuries caused by abiotic stresses (Kowalcyk and Zielony, 2008). They can also act as parts of co-enzymes or as precursors of certain plant hormones and improve plant growth via improving photosynthesis (Amin et al. 2011), mRNA transcription, sugar and protein production (Keutgen and Pawelzik, 2008). They form complexes with metal cations mainly through carboxylate (-C00) and amine ($\mathrm{NH}_{2}$ ) groups, thereby affecting the bioavailability of metals to plants (Aravind and Prasad, 2005).

Glycine acid plays an important role in formation of vegetative growth and chlorophyll. It also has a chelating effect on some micronutrients such as Fe, Zn, $\mathrm{Mn}$, and $\mathrm{Cu}$ through making absorption and transportation easies for the plant (Ghasemi et al. 2013).

L-Methionine is a precursor of ethylene and growth factors such as espermine and espermidine (Singh, 1999). It also has a role in the revitalization of rooting.

Tryptophan helps the formation of indole acetic acid (IAA) and plays an important role in the early growth. Whereas, Phillips (1971) suggested several alternative role of IAA synthesis in plants, all starting from tryptophan, thus when tryptophan is supplied to most plant tissues, IAA was formed. L-tryptophan, the precursor of IAA, is naturally present in root exudates of plants (Villareal et al. 2012). It is also synthesized by hydrolysis of proteins of dead cells (Patten and Glick 1996), and is converted into indole acetic acid by the activity of plant growth promoting rhizobacteria (Sasirekha et al. 2012).

Application of L-tryptophan in soil has proved very fruitful results for increasing growth of many vegetables as well as crops like chickpea (Abbas et al. 2013) and wheat (Mohite, 2013). It is believed that about $80 \%$ of bacterial isolates from rhizosphere soil are capable of synthesizing IAA (Idris et al. 2004). Tryptophan inhibits the precocious flower and fruit fall and it is important in the process of production of enzyme that catalyses' synthesis reaction of auxin (Saburi et al. 2014).

The objective of this investigation was to study the effects of two application methods (Pre-soaking of corms before planting or foliar spray) with different concentrations of three amino acids i.e. glycine, methionine and tryptophan on the vegetative growth, flowering characteristics, corms production and some chemical analysis of Gladiolus grandiflorus cv." Rose Supreme "plants under the circumstance of Alexandria region.

\section{MATERIALS AND METHODS}

The present study was carried out during the season of 2015 at two different locations i.e. nurseries of Department of Floriculture, Ornamental Horticulture and Garden Design Faculty of Agriculture University of Alexandria at Shatby and Montazah Research Branch, Horticulture Institute Ministry of Agriculture, Alexandria, Egypt to investigate the effects of different concentrations and application methods of glycine, methionine and tryptophan on the vegetative growth, flowering characteristics, corms production and some chemical contents of Gladiolus plants. The corms were planted on January 27, 2015 in the two locations and two application methods were used in this experiment, i.e. pre-planting treatment of corms (pre-soaking) or spraying on the plant foliage (foliar - spraying).

The used plant was Gladiolus grandiflorus cv." Rose Supreme "for its popularity in Egypt flower trade. The used corms were obtained from a commercial nursery for flowers and ornamental plants in Cairo city that imported the corms from Netherlands. The used corms had uniform sizes and shape. The average circumference and fresh weight of the chosen corms were $8.87 \mathrm{~cm}$ and $38.73 \mathrm{~g}$ in the two locations. The corms were planted in $30 \mathrm{~cm}$ plastic pots that were filled by the used medium. It was allowed only one bud to grow for each corm to produce one spike for it, with removing any other buds as soon as they appear. All the normal culture practices of growing gladiolus corms were applied as usual manner.

The used medium for planting the corms was a sandy soil (clay $=6 \%$, silt $=4 \%$, and sand $=90 \%$ ) and the chemical analysis of it is shown in Tables A and B. The air temperature and relative humidity (\%) at Shatby and Montazah locations were recorded daily during the growing season and their averages values presented in Table C.

Two application methods were chosen for adding the different concentrations of the three used amino acids i.e. L-glycine, L- methionine and L-tryptophan. These methods were soaking the corms before planting (pre-soaking) and spraying on the plant foliage (foliar spraying). The corms were soaked before planting for $24 \mathrm{hr}$ in the solution of the different concentrations of the used amino acids. Glycine was used at 0 (tap water), 75,225 and $450 \mathrm{ppm}$, methionine was used at 0,150 , 300 and 600 ppm and tryptophan at 0,300, 600 and 900 ppm. Whereas, the foliar spray treatments were done 
early in the morning three times on the foliage until the run - off point. The plants were sprayed at stage of two, four and sex leaves, 34, 48 and 86 days from planting, respectively. The used concentrations were 0 (tap water), 25, 75 and $150 \mathrm{ppm}$ for glycine, 0,50,100 and $200 \mathrm{ppm}$ for methionine and 0,100, 200 and $300 \mathrm{ppm}$ for tryptophan. "Tween 20 " was used at a rate of $1 \mathrm{ml} / 1$ in all sprays as a surfactant substance for enhancing the efficiency of the used materials. While the control plants were sprayed at the same time with tap water containing only the wetting agent (Tween 20).

Each plant under the experiment was fertilized with single calcium superphosphate $\left(\begin{array}{lll}16.5 \% & \left.\mathrm{P}_{2} \mathrm{O}_{5}\right)\end{array}\right)$ at $6 \mathrm{~g}$ (Shah et al. 1984), ammonium nitrate $(33.5 \% \mathrm{~N})$ at $4 \mathrm{~g}$ (Potti and Arora,1986) and potassium sulphate (48\% $\mathrm{K}_{2} \mathrm{O}$ ) at $8 \mathrm{~g}$ (EL-Naggar 1999). Plant requirement of magnesium $(\mathrm{Mg})$ and iron $(\mathrm{Fe})$ was added as $\mathrm{MgSO}_{4} \cdot 7 \mathrm{H}_{2} \mathrm{O}$ (Magnesium Sulphate $=9.5 \% \mathrm{Mg}$ ) and Fe-EDTA (Disodium Fe of chelate ethylene diamine tetra acetic acid $=18 \% \mathrm{Fe}$ ), which were sprayed three times at three weekly intervals on the plant foliage until the run-off point started at 48 days from planting at 150 and $75 \mathrm{ppm}$ for $\mathrm{Mg}$ and $\mathrm{Fe}$, respectively (Taha, 2005).

The experimental layout was designed to provide complete randomized blocks in factorial experiment containing four replicates, each replicate contained 24 different treatments. Three plants were used as a plot for each treatment in each replicate. The means of individual factor and their interactions were compared by L.S.D. test at 5\% level of probability (Snedecor and Cochran, 1974).

Data collected were: Vegetative characteristics; Sprouting period (day), plant height $(\mathrm{cm})$, number of leaves, and leaves dry weight of the cut spike (g).

Flowering characteristics; Time taken from planting date to showing color of the three basal florets (day), number of florets per spike, florets diameter $(\mathrm{cm})$, flower duration on the plant (day), florets dry weight (g), rachis length (zone of florets or flowering portion) in $\mathrm{cm}$. and spike dry weight $(\mathrm{g})$.

Corms and cormels production; Diameter of the new corms $(\mathrm{cm})$, corm fresh weight $(\mathrm{g})$, number of the produced cormels per plant and cormels fresh weight.

Chemical constituents; Total chlorophyll content $(\mathrm{a}+\mathrm{b})$ was determined as SPAD units in the fresh leaves of each plant at flowering stage (100 days after planting). Total carbohydrates content was also determined colourmetricaly at the wave length of 470 $\mathrm{nm}$ as percentage in samples of the new corms for the different treatments as reported by Dubios et al. (1956). Nitrogen content of the new corms as averages was determined in samples of the different treatments by the distillation in Micro-Kjeldahle method as reported by Chapman and Pratt (1961).

The steps of the experiment were repeated in the two locations using the same technique to compare the result of the two locations.

Table A. The chemical analysis of the used medium

\begin{tabular}{cccccccccc}
\hline $\mathbf{p H}$ & $\mathbf{E C}\left(\mathbf{d s m}^{-\mathbf{1}}\right)$ & \multicolumn{3}{c}{ Cations $\left(\mathbf{m e q ~ \mathbf { L } ^ { - 1 }}\right)$} & \multicolumn{3}{c}{ Anions $\left(\mathbf{m e q L}^{-\mathbf{1}}\right)$} \\
\hline & & $\mathbf{C a}^{++}$ & $\mathbf{M g}^{++}$ & $\mathbf{N a}^{+}$ & $\mathbf{K}^{+}$ & $\mathbf{C O}_{\mathbf{3}}^{--}$ & $\mathbf{H C O}_{3}^{-}$ & $\mathbf{C l}^{-}$ & $\mathbf{S O}_{4}^{--}$ \\
\hline
\end{tabular}

Table B. The available macro-and micro-nutrients in the used medium

\begin{tabular}{llccccccc}
\hline & \multicolumn{4}{c}{ Macronutrients $\mathbf{~ m g ~ k g ~}^{-\mathbf{1}}(\mathbf{p p m})$} & \multicolumn{4}{c}{ Micronutrients $\mathbf{~ m g ~ k g ~}^{-\mathbf{1}}$} \\
\hline $\mathbf{N H}_{\mathbf{4}}-\mathbf{N}$ & $\mathbf{N O}_{\mathbf{3}}$ & $\mathbf{N}($ Total) & $\mathbf{P}$ & $\mathbf{K}$ & $\mathbf{C u}$ & $\mathbf{F e}$ & $\mathbf{M n}$ & $\mathbf{Z n}$ \\
\hline 119 & 84 & 203 & 5.8 & 50 & 0.4 & 6.95 & 7.65 & 0.86 \\
\hline
\end{tabular}

Table C. Monthly average of day temperature degree and relative humidity at Shatby and Montazah locations, during the growing season of Gladiolus plants

\begin{tabular}{|c|c|c|c|c|}
\hline Month & $\begin{array}{c}\text { Shatby } \\
\text { Temperature }\left({ }^{0} \mathrm{C}\right)\end{array}$ & Relative humidity(\%) & $\begin{array}{l}\text { Montazah } \\
\text { Temperature }\left({ }^{0} \mathrm{C}\right)\end{array}$ & Relative humidity $(\%)$ \\
\hline February & 17.58 & 59.53 & 15.50 & 51.53 \\
\hline March & 25.68 & 57.00 & 25.35 & 49.41 \\
\hline April & 28.23 & 59.90 & 25.17 & 48.95 \\
\hline May & 32.65 & 60.50 & 28.16 & 55.28 \\
\hline June & 35.50 & 66.53 & 31.60 & 57.40 \\
\hline July & 39.90 & 71.10 & 35.17 & 62.42 \\
\hline August & 39.17 & 64.63 & 34.90 & 57.54 \\
\hline
\end{tabular}


The air temperature and relative humidity (\%) at Shatby and Montazah locations were recorded daily during the growing season and the monthly averages of them are presented in Table (C).

\section{RESULTS AND DISCUSSION}

Generally, the analysis of variance of almost all the collected data of the two locations showed that only the $\mathrm{F}$ values of the amino acids concentrations (C) were significant, while the $F$ values of the other treatments (amino acids type (A), amino acids application methods(B), and their combinations $(\mathrm{AxB}, \mathrm{AxC}, \mathrm{BxC}$, and $\mathrm{AxBxC}$ ) were not significant, with some exceptions.

\section{Vegetative Growth.}

Data of the two locations in Table 1 indicated that using the second and/or the third level of the amino acid concentrations led to significant decrease the sprouting period of the planted corms of Gladiolus grandiflours plants, compared with the other treatments .Also, data of means of the two locations in Table 1 showed that using the second or the third concentration level led to reduce the sprouting period of the planted gladiolus corms with $16.6 \%$ or $14.9 \%$ under the control treatment, respectively. While using the fourth concentration level did not significantly affect the sprouting period, compared with the control treatment.

These results may be due to the role of the used amino acids at a specific concentration in plants. They consider as source for nitrogen, carbon, energy, enzyme, co-enzymes as plant hormones such as indole acetic acid (tryptophan), ethylene (methionine) and others as reported by Amir et al. (2002), Gallardo et al.
(2002) and Saburi et al. (2014) on other plant. These factors led to promote and activate the germination of the planted corms to sprout early. Similar trend of result was found by Taha (2005) on the tuberose plant.

Data presented in Table 1 indicated that using any concentration (level) from the used amino acids gave significant increase of gladioli plant height in the two locations, compared with the control treatment. Besides, there were no significant differences in plant height between the second, or third or fourth concentration. Moreover, the maximum plant height was found at the fourth concentration, which led to increase the plant height with $11.14 \%$ and $17.19 \%$ over the control treatment in Shatby and Montazah locations, respectively. These results may be due to the synergistic effects of the used amino acids at a specific concentration on cell division and growth, consequently the gladioli plant height could be increased. Beside, data in Table 2 of the two locations indicated that there were significant differences between the two used application methods (soaking and foliar spraying) of the amino acids, and the soaking treatment gave the best result. This result was probably due to that soaking the corms before planting in the total concentration of the used amino acids led to enhance the metabolic processes in the corms leading to encourage the growth and cell elongation, consequently the plant height would be increased. Besides, some amino acids (tryptophan) had an effect on gene expression for the production of specific macro-molecules required for permanent cell elongation as reported by Vanderhoef (1980).

Table 1. Effect of the concentrations of the used amino acids on means of sprouting period, plant height, leaves number and leaves dry weight/spike, of Gladiolus grandiflorus cv. "Rose Supreme" in the two locations

\begin{tabular}{|c|c|c|c|c|c|c|c|c|}
\hline \multirow{3}{*}{$\begin{array}{l}\text { Concentr } \\
\text { ation }\end{array}$} & \multicolumn{8}{|c|}{ Characteristics } \\
\hline & \multicolumn{2}{|c|}{ Sprouting period(day) } & \multicolumn{2}{|c|}{ Plant height(cm) } & \multicolumn{2}{|c|}{ Leaves number/plant } & \multicolumn{2}{|c|}{$\begin{array}{c}\text { Leaves dry } \\
\text { weight/spike (g) }\end{array}$} \\
\hline & Shatby & Montazah & Shatby & Montazah & Shatby & Montazah & Shatby & Montazah \\
\hline $\mathrm{CO}$ & $15.49 \mathrm{a}$ & $24.53 \mathrm{a}$ & $76.14 \mathrm{~b}$ & $69.06 \mathrm{~b}$ & 9.50 & 7.72 & $1.55 \mathrm{~b}$ & $1.28 \mathrm{~b}$ \\
\hline $\mathrm{C} 1$ & $13.74 \mathrm{~b}$ & $19.63 \mathrm{~b}$ & $83.91 \mathrm{a}$ & $77.09 \mathrm{a}$ & 9.50 & 7.64 & $2.04 \mathrm{a}$ & $1.70 \mathrm{a}$ \\
\hline $\mathrm{C} 2$ & $13.55 \mathrm{~b}$ & $20.48 \mathrm{~b}$ & $82.74 \mathrm{a}$ & $75.88 \mathrm{a}$ & 9.46 & 7.65 & $2.06 \mathrm{a}$ & $1.78 \mathrm{a}$ \\
\hline C3 & $15.52 \mathrm{a}$ & $21.55 \mathrm{a}$ & $84.62 \mathrm{a}$ & $80.93 \mathrm{a}$ & 9.50 & 7.72 & $2.27 \mathrm{a}$ & $1.83 \mathrm{a}$ \\
\hline Mean & 14.58 & 21.55 & 81.85 & 75.74 & 9.49 & 7.68 & 1.98 & 1.65 \\
\hline L.S.D. & 1.42 & 2.59 & 3.20 & 4.27 & N.S & N.S & 0.18 & 0.19 \\
\hline
\end{tabular}

L.S.D: Least significant differences at 0.05 probability. N.S: Not significant.

$\mathrm{C}_{0}$ : Control (zero ppm).

$\mathrm{C}_{1}: 75,150$ and $300 \mathrm{ppm}$ for glycine, methionine and tryptophan, respectively.

$\mathrm{C}_{2}: 225,300$ and $600 \mathrm{ppm}$ for glycine, methionine and tryptophan, respectively.

$\mathrm{C}_{3}: 450,600$ and $900 \mathrm{ppm}$ for glycine, methionine and tryptophan, respectively. 
Table 2. Effect of the interaction between the used amino acids and the application methods on means of plant height, corms fresh weight and cormels fresh weight in the two locations

\begin{tabular}{|c|c|c|c|c|c|c|c|}
\hline \multirow{3}{*}{$\begin{array}{l}\text { Amino } \\
\text { acid }\end{array}$} & \multirow{3}{*}{$\begin{array}{l}\text { Application } \\
\text { method }\end{array}$} & \multicolumn{6}{|c|}{ Characteristics } \\
\hline & & \multicolumn{2}{|c|}{ Plant Height } & \multicolumn{2}{|c|}{ Corms fresh weight } & \multicolumn{2}{|c|}{ Cormels fresh weight } \\
\hline & & Shatby & Montazah & Shatby & Montazah & Shatby & Montazah \\
\hline \multirow{2}{*}{ Glycine } & Soaking & $82.66 \mathrm{~b}$ & $70.91 \mathrm{~b}$ & $24.59 \mathrm{a}$ & $9.83 \mathrm{~b}$ & $21.80 \mathrm{ab}$ & $9.16 \mathrm{~b}$ \\
\hline & Spraying & $78.50 \mathrm{c}$ & $80.55 \mathrm{a}$ & $23.25 \mathrm{ab}$ & $10.33 \mathrm{~b}$ & $19.52 \mathrm{~b}$ & $12.04 \mathrm{a}$ \\
\hline \multirow{2}{*}{ Methionine } & Soaking & $82.31 \mathrm{bc}$ & $77.10 \mathrm{a}$ & 20.43 c & $12.20 \mathrm{ab}$ & $19.82 \mathrm{~b}$ & $10.87 \mathrm{ab}$ \\
\hline & Spraying & $81.74 \mathrm{bc}$ & $77.05 \mathrm{ab}$ & $22.52 \mathrm{~b}$ & $10.91 \mathrm{~b}$ & $24.90 \mathrm{ab}$ & $11.09 \mathrm{ab}$ \\
\hline \multirow{2}{*}{ Tryptophan } & Soaking & $89.78 \mathrm{a}$ & $71.85 \mathrm{~b}$ & $22.83 \mathrm{ab}$ & $10.58 \mathrm{~b}$ & $26.44 \mathrm{a}$ & $10.10 \mathrm{ab}$ \\
\hline & Spraying & $76.11 \mathrm{c}$ & $76.99 \mathrm{ab}$ & $21.81 \mathrm{bc}$ & $12.93 \mathrm{a}$ & $21.55 \mathrm{ab}$ & $10.43 \mathrm{ab}$ \\
\hline \multicolumn{2}{|c|}{ Mean } & 81.85 & 75.74 & 22.57 & 11.13 & 22.34 & 10.61 \\
\hline \multicolumn{2}{|c|}{ L.S.D. } & 3.93 & 5.23 & 1.90 & 1.98 & 5.44 & 1.95 \\
\hline
\end{tabular}

Least significant differences at 0.05 probability.

$\mathrm{C}_{0}$ : Control (zero ppm).

$\mathrm{C}_{1}: 75,150$ and $300 \mathrm{ppm}$ for glycine, methionine and tryptophan, respectively.

$\mathrm{C}_{2}: 225,300$ and $600 \mathrm{ppm}$ for glycine, methionine and tryptophan, respectively.

$\mathrm{C}_{3}: 450,600$ and $900 \mathrm{ppm}$ for glycine, methionine and tryptophan, respectively.

Furthermore, data of the two locations in Table 2 showed that using the amino acids tryptophan as presoaking treatment gave the maximum plant height of gladioli plant, compared with the other amino acids (glycine and/or methionine) or with the other application method (foliar spraying). These results were probably due to the role of the amino acid tryptophan in plants, which it considers as a precursor for indole acetic acid (IAA) biosynthesis. Consequently, IAA could be promoted and stimulated of cell division and elongation, thus the plant height could be increased as reported by Hanan (2000).

Generally, data in Table 1 indicated that the used amino acids concentrations had no significant effect on the number of leaves per plant in the two locations, and the differences between the used treatments were very small. These results may be probably due to that leaves number of gladioli plant is a genetically character and it is not dependent on the used amino acid treatments. Similar trend of results was reported by Arshad et al. (1993) they reported that using the high level of Lmethionine had either negative or no effect on all plant growth parameters of Albizia lebbeck seedlings,

However, data in Table1 indicated that using any concentration from the used amino acids led to significant increase the dry weight of the leaves per cut spike, compared with the control treatment, and these were no significant differences between $\mathrm{C}_{1}, \mathrm{C}_{2}$ and $\mathrm{C}_{3}$ of the used amino acids. These result was probably due to that using the amino acid at the lowest concentration led to increase the activity of photosynthesis process in gladioli plant, thus the leaves dry weight per cut spike could be increased. Similar trend of results was reported by El-Awadi and Abd ELWahid (2012).

\section{Flowering characteristics:}

Data of the two locations in Table 3 indicated that the effects of the used treatments on the time of flowering of gladioli plant were not significant. These result may be probably due to that the used amino acids with their concentrations and the application methods had no effect on the time of flowering of the cultivar "Rose Supreme", and the plants flower only when they reach to a proper maturity stage.

Generally, data of the two locations in Table 3 indicated that using any concentration from the used amino acids (glycine, methionine and tryptophan) led to significant increase of the number of florets per spike, compared with the control treatment. Also, these were no significant differences between $C_{1}, C_{2}$ and $C_{3}$ and they had equal effects on the number of florets per spike. These results may be due to the role of the used amino acids at a specific concentration on improving the vegetative growth of gladioli plant, consequently the production and accumulation of the biosynthesizes could be increased, thus the number of florets per spike could be increased. Similar trend of results was found by Ahmad et al. (2007 and 2008) on other plants.

With respect to florets diameter data of the two locations in Table 3 indicated that using any concentration from the used amino acids led to significant increase the florets diameter of gladioli plant, compared with the control treatment, and there were no significant differences between $\mathrm{C}_{1}, \mathrm{C}_{2}$ and $\mathrm{C}_{3}$ of the used amino acids. These results may be due to the effects of the used amino acids on activating the endogenous hormones or their precursors which ultimately help to increase the florets quality of gladioli plant, thus the florets diameter could be increased as 
reported by Ahmad and Anwar (1999). Similar trend of results was reported by Taha (2005) on tuberose plant.

Furthermore, data of the two locations in Table 6 generally, indicated that the amino acid methionine had superior effect on the florets diameter of gladioli plant in comparison with the other amino acids i.e. glycine or tryptophan. These results may be due to the role of the amino acid methionine which it is consider as the source of nitrogen and sulphur major nutrients and their attribution to biosynthesis of other amino acids as cysteine and glutathione as well as their protect to metabolites of the oxidation as reported by El-Awadi and Abd ELWahed (2012), consequently the vegetative growth of gladioli could be encouraged, thus the flowering quality could be increased.

Also, the results of the two locations in Table 3 indicated that using any concentration from any amino acid led to significant increase of the flowering period of gladioli plant, compared with the control treatment, and there were no significant differences between the used concentrations $\left(\mathrm{C}_{1}, \mathrm{C}_{2}\right.$ and $\left.\mathrm{C}_{3}\right)$ of the amino acids. These results may be due to that using any amino acid with any concentration led to stimulate the vegetative growth of the plants, consequently the flowering period could be increased.

Besides, data in Table 4 indicated that using any concentration $\left(\mathrm{C}_{1}\right.$ or $\mathrm{C}_{2}$ or $\left.\mathrm{C}_{3}\right)$ from any amino acids (glycine, or methionine or tryptophan) significantly increased the dry weight of the florets per spike, compared with the control treatment in the two locations, and there were no significant differences between the different concentrations $\left(\mathrm{C}_{1}, \mathrm{C}_{2}, \mathrm{C}_{3}\right)$ of the used amino acids. Also, the maximum dry weight of the florets per spike is a mean for the two locations was obtained at $\mathrm{C}_{3}$. These results may be due to the effect of the used amino acids at a specific concentration on increasing the florets number or size or both of them, consequently the dry weight of the florets per spike could be increased. Similar trend of result was reported by Taha (2005) on tuberose plant.

Generally, data on means of spike length presented in Table 4 indicated that using the highest concentration of the used amino acids (450 ppm for glycine or 600 ppm for methionine or 900 ppm for tryptophan) gave significant increase of spike length in both locations, compared with the other concentrations, and this treatment led to increase the spike length with $14.55 \%$ over the control treatment as a mean of the two locations. These results may be due to the synergistic effect of the used amino acids at a suitable concentration on gladioli growth, as a result of their functions as stimulate of cell division and many enzymes activities, consequently the spike length could be increased. Similar trend of results was reported by Ahmad and Anwar (1999) on other plants.

Data of the two experimental locations presented in Table 4 indicated that using any concentration $\left(\mathrm{C}_{1}, \mathrm{C}_{2}\right.$, $\mathrm{C}_{3}$ ) from the used amino acids (glycine, methionine and tryptophan) gave significant increase of the spike dry weight, compared with the control treatment. Besides, there were no significant differences between the used concentrations $\left(\mathrm{C}_{1}, \mathrm{C}_{2}\right.$ and $\left.\mathrm{C}_{3}\right)$. Also, using the highest concentration $\left(\mathrm{C}_{3}\right)$ led to increase the spike dry weight with $47.66 \%$ over the control treatment as a mean of the two locations. These results may be due to the effect of the used amino acids at a suitable concentration on increasing spike length or spike diameter or both of them, consequently the spike dry weigh could be increased. Similar trend of results was reported by Taha (2005) on tuberose plants.

Table 3. Effect of the concentrations of the used amino acids on means of flowering time, number of florets/spike, florets diameter, and flower duration of Gladiolus grandiflorus cv. "Rose Supreme" in the two locations

\begin{tabular}{ccccccccc}
\hline Concentration & \multicolumn{9}{c}{ Flowering Characteristics } \\
& \cline { 2 - 9 } & Flowering time(day) & \multicolumn{2}{c}{ No. of florets/spike } & \multicolumn{2}{c}{$\begin{array}{c}\text { Florets } \\
\text { diameter(cm) }\end{array}$} & \multicolumn{2}{c}{$\begin{array}{c}\text { Flower } \\
\text { duration(day) }\end{array}$} \\
\cline { 2 - 9 } & Shatby & Montazah & Shatby & Montazah & Shatby & Montazah & Shatby & Montazah \\
\hline C0 & 102.99 & 114.88 & $11.87 \mathrm{~b}$ & $11.54 \mathrm{~b}$ & $9.98 \mathrm{~b}$ & $11.59 \mathrm{~b}$ & $17.65 \mathrm{~b}$ & $15.76 \mathrm{~b}$ \\
$\mathrm{C} 1$ & 101.92 & 114.16 & $13.45 \mathrm{a}$ & $13.32 \mathrm{a}$ & $10.66 \mathrm{a}$ & $12.42 \mathrm{a}$ & $20.00 \mathrm{a}$ & $17.17 \mathrm{a}$ \\
$\mathrm{C} 2$ & 102.73 & 114.71 & $13.32 \mathrm{a}$ & $12.39 \mathrm{a}$ & $10.71 \mathrm{a}$ & $12.59 \mathrm{a}$ & $20.31 \mathrm{a}$ & $17.29 \mathrm{a}$ \\
$\mathrm{C} 3$ & 102.48 & 115.25 & $13.19 \mathrm{a}$ & $12.59 \mathrm{a}$ & $10.66 \mathrm{a}$ & $12.84 \mathrm{a}$ & $20.33 \mathrm{a}$ & $17.22 \mathrm{a}$ \\
Mean & 102.53 & 114.75 & 12.96 & 12.21 & 10.50 & 12.36 & 19.57 & 16.86 \\
L.S.D. & N.S & N.S & 0.55 & 0.65 & 0.30 & 0.40 & 0.79 & 0.43 \\
\hline
\end{tabular}

L.S.D: Least significant differences at 0.05 probability. N.S: Not significant.

$\mathrm{C}_{0}$ : Control (zero ppm).

$\mathrm{C}_{1}: 75,150$ and $300 \mathrm{ppm}$ for glycine, methionine and tryptophan, respectively.

$\mathrm{C}_{2}: 225,300$ and $600 \mathrm{ppm}$ for glycine, methionine and tryptophan, respectively.

$\mathrm{C}_{3}: 450,600$ and $900 \mathrm{ppm}$ for glycine, methionine and tryptophan, respectively. 
Table 4. Effect of the concentrations of the used amino acids on means of florets dry weight, spike length and spike dry weight of Gladiolus grandiflorus cv. "Rose Supreme" in the two locations

\begin{tabular}{|c|c|c|c|c|c|c|}
\hline \multirow{3}{*}{ Concentration } & \multicolumn{6}{|c|}{ Flowering Characteristics } \\
\hline & \multicolumn{2}{|c|}{ Florets dry weight(g) } & \multicolumn{2}{|c|}{ Spike length $(\mathrm{cm})$} & \multicolumn{2}{|c|}{ Spike dry weight(g) } \\
\hline & Shatby & Montazah & Shatby & Montazah & Shatby & Montazah \\
\hline $\mathrm{CO}$ & $1.69 \mathrm{~b}$ & $2.39 \mathrm{~b}$ & $43.34 \mathrm{~b}$ & $32.70 \mathrm{~b}$ & $1.46 \mathrm{~b}$ & $1.10 \mathrm{~b}$ \\
\hline $\mathrm{C} 1$ & $2.33 \mathrm{a}$ & $3.06 \mathrm{a}$ & $43.83 \mathrm{~b}$ & $38.49 \mathrm{a}$ & $1.94 \mathrm{a}$ & $1.59 \mathrm{a}$ \\
\hline $\mathrm{C} 2$ & $2.30 \mathrm{a}$ & $3.38 \mathrm{a}$ & $43.71 \mathrm{~b}$ & $36.94 \mathrm{a}$ & $1.95 \mathrm{a}$ & $1.70 \mathrm{a}$ \\
\hline C3 & $2.34 \mathrm{a}$ & $3.37 \mathrm{a}$ & $48.20 \mathrm{a}$ & $38.90 \mathrm{a}$ & $2.01 \mathrm{a}$ & $1.76 \mathrm{a}$ \\
\hline Mean & 2.17 & 3.05 & 44.77 & 36.76 & 1.84 & 1.54 \\
\hline L.S.D. & 0.20 & 0.37 & 3.67 & 1.64 & 0.20 & 0.18 \\
\hline
\end{tabular}

Least significant differences at 0.05 probability.

$\mathrm{C}_{0}$ : Control (zero ppm).

$\mathrm{C}_{1}: 75,150$ and $300 \mathrm{ppm}$ for glycine, methionine and tryptophan, respectively.

$\mathrm{C}_{2}: 225,300$ and $600 \mathrm{ppm}$ for glycine, methionine and tryptophan, respectively.

$\mathrm{C}_{3}: 450,600$ and $900 \mathrm{ppm}$ for glycine, methionine and tryptophan, respectively.

\section{Corms and cormels production}

Generally, data of the two locations in Table 5 indicated that using any concentration $\left(\mathrm{C}_{1}, \mathrm{C}_{2}, \mathrm{C}_{3}\right)$ from the used amino acids led to significant increment of the diameter of the new corms of gladioli plant, compared with the control treatment, and there were no significant differences between the used concentrations $\left(\mathrm{C}_{1}, \mathrm{C}_{2}\right.$ and $\mathrm{C}_{3}$ ). These results may be due to the role of the used amino acids at a specific concentration on the plant growth, which had a positive effect on photosynthetic and respiration rates and leaf carbohydrate as reported by Dhopte and Lail (1987) and this will reflect on the nutrients uptake and transport, consequently produced good plant with large leaves which could be storage a large amount of foods in the corms, thus the new corms diameter could be increased. These results are in agreement with those reported by Gonzalez et al. (1994) on Allium cepa El-Shabasi et al. (2005) on garlic and Taha (2005) on tuberose plant.

Also, data of the two locations presented in Table 6 indicated that using amino acid tryptophan gave the maximum corms diameter, compared with the two other amino acids (glycine or methionine). These results may be due to the role of tryptophan in plants. L-tryptophan is known physiological as a precursor of indole acetic acid and its application at appropriate concentration could have a positive effect on plant growth because slow and gradually continuous release of indole acetic acid from L-tryptophan, consequently the new corms diameter could be increased. Similar trend of results was reported by Zahir et al. (1997) and Ahmad et al. (2008) on other plants.

With respect to corms fresh weight data of the two locations presented in Tables 2,5 and 6 indicated that using the lowest concentration from any of the used amino acids, especially tryptophan at $300 \mathrm{ppm}$ as a foliar spraying on Gladiolus plant gave the maximum significant increase of corms fresh weight, compared with the other treatments.

These results were probably due to the role of tryptophan as an efficient physiological precursor of auxins in higher plants (Arshad and Frankenberger, 1991), which led to stimulate the gladioli growth, consequently producing bigger corms, thus their fresh weight could be increased.

Besides, data of the two locations presented in Table 5 showed that using the first concentration of the used amino acids (75 ppm for glycine, $150 \mathrm{ppm}$ for methionine and $300 \mathrm{ppm}$ for tryptophan) gave the highest significant number of the produced cormels per plant, compared with the other concentrations. This treatment led to increase the number of the produced cormels per plant with $50.05 \%$ over the control treatment as a mean of the two locations (Table 5).

These results may be attributed to that using the amino acids at a suitable concentration led to promote plant growth (Coruzzi and Last, 2000), accordingly resulted in more translocation and accumulation of carbohydrates and proteins, thus the cormels production could be increased.

Similar results were reported by Awadi et al. (2007) on garlic and Amin et al. (2011) on onion.

Also, data of the two locations presented in Table 5 indicated that the first concentration from the used amino acids (75 ppm for glycine, $150 \mathrm{ppm}$ for methionine and $300 \mathrm{ppm}$ for tryptophan) gave the highest significant cormels fresh weight, compared with the other concentrations. This treatment led to increase the cormels fresh weight with $57.05 \%$ over the control treatment as a mean for the two locations. 


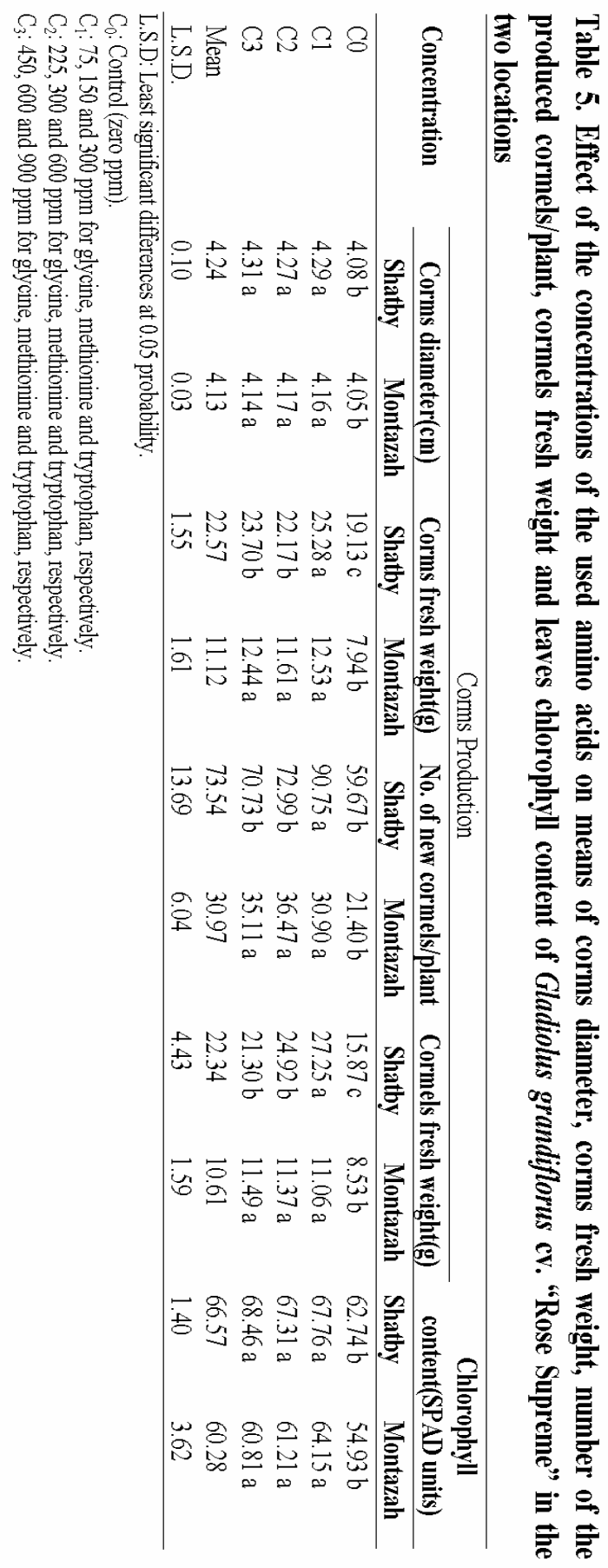


Table 6. Effect of the used amino acids on means of florets diameter, corms diameter and corms fresh weight in the two locations

\begin{tabular}{lcccccc}
\hline \multirow{2}{*}{ Amino acid } & \multicolumn{9}{c}{ Characteristics } \\
\cline { 2 - 7 } & \multicolumn{2}{c}{ Florets diameter } & \multicolumn{2}{c}{ Corms diameter } & \multicolumn{2}{c}{ Corms fresh weight } \\
\cline { 2 - 7 } & Shatby & Montazah & Shatby & Montazah & Shatby & Montazah \\
\hline Glycine & $10.23 \mathrm{~b}$ & $12.66 \mathrm{a}$ & $4.23 \mathrm{ab}$ & $4.14 \mathrm{ab}$ & $23.92 \mathrm{a}$ & $10.08 \mathrm{~b}$ \\
Methionine & $10.63 \mathrm{a}$ & $12.43 \mathrm{a}$ & $4.18 \mathrm{~b}$ & $4.11 \mathrm{~b}$ & $21.47 \mathrm{~b}$ & $11.56 \mathrm{a}$ \\
Tryptophan & $10.42 \mathrm{ab}$ & $11.98 \mathrm{~b}$ & $4.30 \mathrm{a}$ & $4.15 \mathrm{a}$ & $22.32 \mathrm{~b}$ & $11.75 \mathrm{a}$ \\
Means & 10.43 & 12.36 & 4.24 & 4.13 & 22.57 & 11.13 \\
L.S.D. & 0.26 & 0.35 & 0.09 & 0.03 & 1.34 & 1.39 \\
\hline
\end{tabular}

Least significant differences at 0.05 probability.

These results were probably due to the role of the used amino acids at a suitable concentration in the stimulation and improvement of the growth, through activating the endogenous hormones or their precursors which help to increase the number or size or both of the new cormels per plant, consequently the cormels fresh weight could be increased.

These results are in accordance with those of Islam et al. (1983), Ahmad and Tahir (1995) and Ahmad and Anwar (1999) on the other plants.

Furthermore, data of the means of cormels fresh weight of the two locations presented in Table 2 indicated that using the amino acid tryptophan as a presoaking treatment gave the highest significant increase of the cormels fresh weight, compared with the other amino acids and the other application method (foliarspraying). This treatment led to increase the cormels fresh weight with $18.02 \%$ over the control treatment. These results were probably due to the role of the amino acid tryptophan in plants. Tryptophan is a physiological precursor of indole acetic acid (IAA) and its application at a suitable concentration and method could have a positive effect on plant growth because of slow and gradually continuous release of IAA from tryptophan as reported by Frankenberger and Poth (1987) and Zahir et al. (1997), thus the plant could be produced large number or size or both of cormels, consequently the fresh weight of the produced cormels would be increased. Similar trend of results was reported by Ahmad and Anwar (1999) and Ahmad et al. (2008).

\section{Chemical analysis:}

Generally, data of the two locations presented in Table 5 indicated that using any concentration $\left(\mathrm{C}_{1}, \mathrm{C}_{2}\right.$, $\mathrm{C}_{3}$ ) from the used amino acids led to significant increase the content of total chlorophyll in gladioli leaves, compared with the control treatment, and there were no significant differences between the used concentrations $\left(\mathrm{C}_{1}\right.$ or $\mathrm{C}_{2}$ or $\left.\mathrm{C}_{3}\right)$. Also, the maximum chlorophyll value was found at the first concentration level as a mean of the two experimental locations, which led to increase the chlorophyll content in gladioli leaves with $12.1 \%$ over the control treatment. These results may be probably due to the role of the used amino acids at a suitable concentration which they consider as sources for nitrogen and carbon as structural components of chlorophyll and enzymes needed for chlorophyll formation. Similar trend of results was reported by Islam et al. (1983), Ahmad and Anwar (1999), Taha (2005) and EL-Awadi and Abd El-Wahed (2012).

Besides, data of the two locations on the average of total carbohydrate (\%) in the produced corms of Gladiolus plant showed that generally, using any amino acid led to increase the content of the new corms at total carbohydrate (\%), compared with the control treatment, with two exceptions of methionine and tryptophan in one location; "Montazah" (Table 7). These results may be probably due to the role of the used amino acids in plants. They consider as sources of nitrogen, carbon, enzymes, co-enzymes and plant hormones needed for increasing the back translocation of the output of photosynthesis process, consequently the percentage of the total carbohydrate in the new corms could be increased.

Furthermore, data of the two location in Table 7 indicated that using the amino acid methionine gave the maximum average of the total carbohydrate content in the produced corms, compared with the other two amino acids (glycine and tryptophan). These results were probably due to that using the amino acid methionine led to increase the efficient of photosynthesis process, through increasing the leaf pigments (chlorophyll a , b and carotenoids), consequently the assimilated food could be increased, thus the storage carbohydrate in the new corms would be increased. Similar trend of result was found by Amin et al. (2011) and EL-Awadi and Abd-Wahed (2012) on onion plant.

With respect to the average of nitrogen content (\%) of the produced corms of Gladiolus plant data of the two locations in Table 8 indicated that using any amino acid (glycine or methionine or tryptophan) led to increase the content of nitrogen of the new corms, compared with the control treatment. 
Table 7. Means of total carbohydrate content (\%) of the produced corms of Gladiolus grandiflorus cv. "Rose Supreme" as influenced by the concentration and application method of glycine, methionine and tryptophan in the two locations

\begin{tabular}{|c|c|c|c|c|c|c|c|c|}
\hline \multirow{3}{*}{ Amino acid } & \multirow{3}{*}{$\begin{array}{l}\text { Conc. } \\
\text { (ppm) }\end{array}$} & \multicolumn{7}{|c|}{ Application Method } \\
\hline & & \multicolumn{3}{|c|}{ Pre-soaking } & \multirow{2}{*}{$\begin{array}{l}\text { Conc. } \\
\text { (ppm) }\end{array}$} & \multicolumn{3}{|c|}{ Foliar spraying } \\
\hline & & Shatby & Montazah & Mean & & Shatby & Montazah & Mean \\
\hline \multirow{5}{*}{ Glycine } & 0 & 40.18 & 42.55 & 41.37 & 0 & 42.80 & 35.10 & 38.95 \\
\hline & 75 & 39.80 & 42.80 & 41.30 & 25 & 42.40 & 41.90 & 42.15 \\
\hline & 225 & 42.60 & 39.30 & 40.95 & 75 & 34.90 & 38.70 & 36.80 \\
\hline & 450 & 46.08 & 39.60 & 42.84 & 150 & 44.15 & 40.80 & 42.48 \\
\hline & Mean & 42.17 & 41.06 & 41.62 & Mean & 41.06 & 39.13 & 40.10 \\
\hline \multirow{5}{*}{ Methionine } & 0 & 40.45 & 36.70 & 38.58 & 0 & 40.80 & 49.32 & 45.06 \\
\hline & 150 & 44.10 & 46.12 & 45.11 & 50 & 39.60 & 41.20 & 40.40 \\
\hline & 300 & 49.20 & 40.15 & 44.68 & 100 & 42.20 & 43.30 & 42.75 \\
\hline & 600 & 40.16 & 44.30 & 42.23 & 200 & 39.90 & 40.80 & 40.35 \\
\hline & Mean & 43.48 & 41.82 & 42.65 & Mean & 40.63 & 43.66 & 42.14 \\
\hline \multirow{5}{*}{ Tryptophan } & 0 & 40.18 & 43.50 & 41.84 & 0 & 40.50 & 43.50 & 42.00 \\
\hline & 300 & 48.15 & 46.28 & 47.22 & 100 & 46.25 & 35.70 & 40.98 \\
\hline & 600 & 40.13 & 39.75 & 39.94 & 200 & 35.80 & 40.30 & 38.05 \\
\hline & 900 & 44.20 & 44.17 & 44.19 & 300 & 43.20 & 40.20 & 41.70 \\
\hline & Mean & 43.17 & 43.43 & 43.30 & Mean & 41.44 & 39.93 & 40.68 \\
\hline
\end{tabular}

Table 8. Means of total nitrogen content (\%) of the produced corms of Gladiolus grandiflorus cv." Rose Supreme " as influenced by the concentration and application method of glycine, methionine and tryptophan in the two locations

\begin{tabular}{|c|c|c|c|c|c|c|c|c|}
\hline \multirow{3}{*}{ Amino acid } & \multirow[t]{3}{*}{ Conc. (ppm) } & \multicolumn{7}{|c|}{ Application Method } \\
\hline & & \multicolumn{3}{|c|}{ Pre-soaking } & \multirow{2}{*}{$\begin{array}{l}\text { Conc. } \\
\text { (ppm) }\end{array}$} & \multicolumn{3}{|c|}{ Foliar spraying } \\
\hline & & Shatby & Montazah & Mean & & Shatby & Montazah & Mean \\
\hline \multirow{5}{*}{ Glycine } & 0 & 4.20 & 2.10 & 3.15 & 0 & 4.90 & 4.45 & 4.67 \\
\hline & 75 & 5.95 & 2.80 & 4.38 & 25 & 5.60 & 2.17 & 3.89 \\
\hline & 225 & 4.20 & 7.00 & 5.60 & 75 & 4.55 & 5.25 & 4.90 \\
\hline & 450 & 3.50 & 5.60 & 4.55 & 150 & 6.30 & 2.10 & 4.20 \\
\hline & Mean & 4.46 & 4.38 & 4.42 & Mean & 5.34 & 3.49 & 4.56 \\
\hline \multirow{5}{*}{ Methionine } & 0 & 5.95 & 2.80 & 4.38 & 0 & 3.00 & 2.50 & 2.75 \\
\hline & 150 & 4.90 & 7.00 & 5.95 & 50 & 1.68 & 1.40 & 1.54 \\
\hline & 300 & 7.00 & 7.35 & 7.18 & 100 & 7.35 & 1.40 & 4.38 \\
\hline & 600 & 7.00 & 6.30 & 6.65 & 200 & 7.00 & 1.68 & 4.34 \\
\hline & Mean & 6.21 & 5.86 & 6.04 & Mean & 4.76 & 1.75 & 4.36 \\
\hline \multirow{5}{*}{ Tryptophan } & 0 & 4.90 & 1.40 & 3.15 & 0 & 4.90 & 2.24 & 3.57 \\
\hline & 300 & 4.20 & 1.40 & 2.80 & 100 & 4.90 & 2.10 & 3.50 \\
\hline & 600 & 7.00 & 2.45 & 4.73 & 200 & 5.60 & 1.54 & 3.57 \\
\hline & 900 & 4.20 & 1.40 & 2.80 & 300 & 4.55 & 0.70 & 2.63 \\
\hline & Mean & 5.08 & 1.66 & 3.37 & Mean & 4.99 & 1.65 & 3.32 \\
\hline
\end{tabular}

These results were probably due to the role of amino acids in plants, which are considered the building block of protein and serve as parts of co-enzymes or as precursors of certain plant hormones and improve plant growth via improving photosynthesis (Amin et al. 2011), consequently the nitrogen content in the new corms could be increased. Similar trend of results was reported by Wahba et al. (2002) on Antholyza aethiopica plant and El-Shabasi et al. (2005) on garlic plant.

Besides, data in Table 8 showed that using the amino acid methionine at $300 \mathrm{ppm}$, regardless of the application method (means of the two locations) gave the maximum value of the nitrogen content in the produced corms, compared with the other treatments. These results may be due to that methionine acts as 
source of nitrogen and sulphur major nutrients and their attribution to biosynthesis of other amino acids as cysteine and glutathione as well as their protect to metabolites oxidation (El-Awadi and Abd El Wahed, 2012), consequently the nitrogen content of the new corms could be increased. Similar trend of result was reported by Arshad et al. (1993) on Albizia lebbeck seedling.

\section{REFERENCES}

Abbas, S.H., M. M. Sohail, M. Saleem, M. Tariq, I. Aziza, M. Qammar, A. Majeed and M. Arip. 2013. Effect of Ltryptophan on plant weight and pod weight in chickpea under rain fed conditions Sci. Tech. Dev. 32(4) 227-280.

Ahmad, C.M. and M. Taher. 1995. Effect of mixture of $\mathrm{GA}_{3}$, NAA and BA on some of the yield parameters of Solanum tuberosum L. Sarhad J.Agri.11:133-137.

Ahmad, M. and U. Anwar. 1999. International. Journal. of Agriculture \& Biology.1560-8530. 01-1/2-030-032.

Ahmad, R., K. Azeem, A. Muhammad, Z. Zahir and M. Tariq. 2008. Effect of compost enriched with $\mathrm{N}$ and Ltryptophan on soil and maize. Agron. Sustain. Dev. 28.299-305.

Ahmad, R., S.M. Shahzad, A. Khalid, M. Arshad and M. H. Mahmood. 2007. Growth and yield response of wheat (Triticum aestivum L.) and maize (Zea mays L.) to nitrogen and L-tryptophan enriched compost. Pak. J. Bot., 39: 541-549.

Amin, A. A., A. E. Fatma, M. Gharib, El-Awadi and S. M. Rashad. 2011. Physiological response of onion plants to foliar application of putrescine and glutamine, Scientia Horticulture, Volume 129: 353-360.

Amir, R., Y. Hacham and G. Galili. 2002. Cystathionine Ysynthase and threonine synthase operate in concert to regulate carbon flow towards methionine in plants. TRENDS in Plant Science Vol.7 No.4 April.

Aravind, P. and M. Prasad. 2005. Cadmium-induced toxicity reversal by zinc in Ceratophyllum deinersum L. (a free floating aquatic macrophyte) together with exogenous supplements of amino-and organic acids. Chemosphere: 611:7 20-33

Arshad, M. Altaf, H. Muhammad and T. William. 1993. Effect of soil applied L-methionine on growth, nodulation and chemical composition of Albizia lebbeck L. Plant and Soil 148: 129-135.

Arshad, M. and W. T. Frankenberger. 1991. Yield Response of Watermelon and Muskmelon to L-Tryptophan Applied. Hortscience 26 (1): 35-37.

Aslam, M., R. Travis and D. Rains. 2001. Differential effect of amino acid on nitrate uptake and reduction systems in barley roots. Plant Science. 160 (2): 219-228.

Awadi, M. A., M. Abd El-Hameed and Z. Shall. 2007. Effect of glycine, lysine and nitrogen fertilizer rates on growth, yield and chemical composition of potato. J. Agric. Sci. Mansoura Univ., 32: 8541-8551.
Chapman, D. and E. Pratt. 1961. Methods of analysis for soil, plants and water. Univ. Div. Agric. Sci. Calif., U.S.A.

Coruzzi, G. and R. Last. 2000. Amino acids. In: Biochemistry and Molecular Biology of Plant. Buchanan, W. Gruissem, R. Jones(ends). Amer.Soc. Plant Biol., Rockville, MD, USA(pub), pp.358-410.

Dhopte, A. and S. Lail. 1987. Relative efficiency of antitranspirant, growth regulators and mineral nutrients in hirsutum cotton under dry land conditions, Ann. Plant Physiol.1(1): 56-71.

Dubios, M., A. Gilles, A. Hamilton, K. Rebers, A. and F. Smith. 1956. Colorimetric method for determination of sugars and related substances. Annal.Chem. 28(3) 350-6.

El-Awadi, E. M. and S. Abd El-Wahed. 2012. Improvement the Growth and Quality of Green Onion (Allium Cepa L.) Plants by Some Bio regulators in the New Reclaimed Area at Nobaria Region, Egypt. New York Science Journal, 5(9).

El-Naggar, A. H. 1999. Effect of potassium and gibberellic acid on the vegetative growth, flowering, corms and cormels production of gladiolus plants in sandy desert soil. Ph.D. Thesis, Hort.Flori. Dept., Fact. Of Agric., Alex. Univ.

El-Shabasi, M. S., S. Mohamed and Sanaa, A. Mahfouz. 2005. Effect of Foliar Spray with some Amino Acids on Growth, Yield and Chemical Composition of Garlic Plants. Hort. Res. Inst., Agric. Res. Centre. Cairo. Egypt.

Frankenberger, W. and M. Poth. 1987. Biosynthesis of indole3 -acetic acid by the pine ectomycorrhizal fungus Pisolithius tinctorius. AppI. Environ. Microbiol.53: 29082913.

Gallardo, Karine, J. Claudette, P. Steven, P. Maged, D. Hans, V. Joel and J. Dominique. 2002. Importance of methionine biosynthesis for Arabidopsis seed germination and seedling growth. Phsiologia Plantarum 116: 238-247.

Ghasemi, S., A. Khoshgftarmanesh, H. Hadadzadeh and M. Afyuni. 2013. Synthesis, characterizatiation and theoretical and experimental investigations (11) -Amino acid complexes as ecofriendly plant growth promoters and highly bioavailable sources of zinc. J. Plant Growth Regul 32: 315-323 .

Gonzalez, A., A. Hidalgo, A. Calcr, R. Palos and P. Navas. 1994. Nutrient uptake changes in ascorbate free radical stimulated onion roots. Plant physiology 104(1):271-276.

Goss, A. 1973. Amino acid synthesis and metabolism. Physiology of plants and their cells. Pergamon Press INC, New York-Toronto, Oxford, Sydney, Braunschweig.202.

Hanan, Z. 2000. Effect of tryptophan and paclobutrazol on Caraway (Carum carvil L.) and Coriander (Coriandrum sativum L.) plants. M. S. C. Thesis. Fac. of Agric., Cairo.

Idris, E., E. Bochow, H. Ross and R. Borriss. 2004. Use of Bacillus subtilis as biocontrol agent.1111. Phytohormone like action of culture filtrates prepared from plant growth promoting Bacillus amyloli quefaciens FZB 24, 42, 45 and Bacillus subtilis F2B 37. J. Plant Dis.Prot.111.583590. 
Islam, M.T., S. M. Alam and A. Mushi. 1983. Effect of some phytohormones on the production efficiency of potato. Bangladesh Hort., 11:44-7.

Keutgen, Anna, J. and Elke, Pawelzik 2008. Contribution of amino acids to strawberry fruit quality and their relevance as stress indicators under $\mathrm{Na} \mathrm{Cl}$ salinity. Food Chemistry 111.642-647.

Kowalczyk, K. and T. Zielon. 2008. Effect of Amino plant and Asahi on yield and quality of lettuce grown on Rockwool. Book of Abstracts of the Conference of bio stimulators in modern agriculture, 7-8 February, Warsaw, Poland, 40.

Mohite, B. 2013. Isolation and characterization of indole acetic acid (IAA) producing bacteria from rhizosphere soil and its effect on plant growth. J. Soil Sci.Plant Nutr. 13 (3). 619-638

Patten, C. and B.R.Glick. 1996. Bacterial biosynthesis of indole-3-acetic acid. Canada. J. Micro.42.207-220.

Persson, J., P. Hogberg, A. Ekblad, M. Hogberg, A. Nordgren and T. Nasholm. 2003. Nitrogen acquisition from inorganic and organic sources by boreal forest plants in the field. Oecologia.137(2):252-257.

Phillips, D. 1971. Introduction to the Biochemistry and Physiology of plant Growth Hormones. Copyright p.12 McGraw-Hill Book Co. New York.

Potti, S. K. and J.S. Arora. 1986. Nutrition studies in Gladiolus cv. "Sylvia". I. Effect of P.and K on growth, flowering, corm and cormel production. Punjab Horticulture Journal, 26:125-128.

Saburi, Maryam., R. Mohammad, H. Sayed, S. Mohammad and D. Taghi. 2014. Effects of amino acids and nitrogen fixing bacteria on quantitative yield and essential oil content of basil (Ocimum basilicum). Agric.Sci. Dev, No (8). pp.265-268.
Sasirekha, B., K.S. Shiva Kumar and S.B. Sullia. 2012. Statistical optimization for improved indole-3- acetic acid (IAA) production by Pseudomonas aeruginosa and demonstration of enhanced plant growth promotion Soil Sci.Plant Nutr. 12 (4), 863-873.

Shah, A., S.B. Lal, and J.N. Sethi. 1984. Effect of different level of $\mathrm{N}$ and $\mathrm{P}$ on growth, flowering and yield of Gladiolus cv. Vinks Glory. Prog. Hort., 16: 305-7.

Singh, B. K. 1999. Plant amino acids: Biochemistry and Biotechnology. Marcel Dekker.Inc., New York, U.S.A, P.648.

Snedecor, G. and W. Cochran. 1974. Statistical methods. Sixth Edition. Iowa State University Press. Ames. Iowa. USA.

Taha, Asmaa, M. 2005. Effect of concentration and application methods of ascorbic acid, thiamine and tryptophan on the growth of tuberose plants. Thesis. Fac.of Agric.Alex.

Vanderhoef, N. 1980. Auxin-regulated cell enlargement: is there action at the level of gene expression? In Genome Organization and Expression in Plants,159-73, Leave, C.J. ed. Plenum New York.

Villarreal, S.Q., N. Hernandez, L. Romero, E. Lazcano and A. Dorantes. 2012. Assessment of plant growth promotion by rhizobacteria supplied with tryptophan as phytohormone production elicitor on Axon opus affinis.Agri.Sci.Res.J. 2(11). 574-580.

Wahba, H. E., M. M. Safaa, G. E. Attoa and A.A. Farahat. 2002. Response of Antholyza acthipoica L.to foliar spray with some amino acids and mineral nutrition with Sulphur. Ann Agric.Sci.Ciro.Univ.,47(3):929-944.

Zahir, Z. A., M. Arshad, M. Azam and A. Hussain. 1997. Effect of an auxin precursor L-tryptophan and Azotobacter inoculation on yield and chemical composition of potato under fertilized conditions. J. Plant Nutr.20.745-752. 


\section{المالهص المرب \\ تأثير الجليسن والميشيونين والترنتولن عل النو الخضرى والزهرى وإنتاج الكورملت ف نبلت

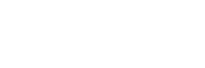 \\ محمود خطلب، أثررف مصطفى، إيملن أبوللسعادات، خميس الهسف الهن}

وبعض النحليلات الكيماوية) بالمقارنة بالكنترول ، بينما كلن

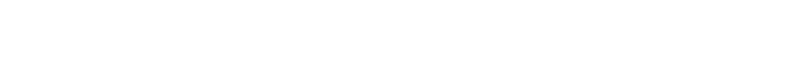

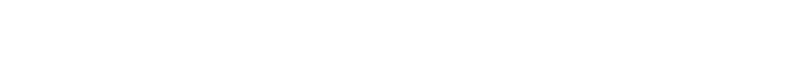
بدء التزهير غير معنوى بالمقارنة بالكنترول.

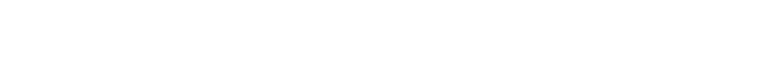

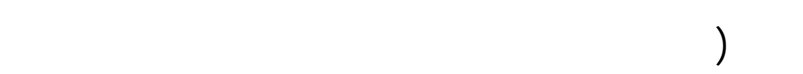

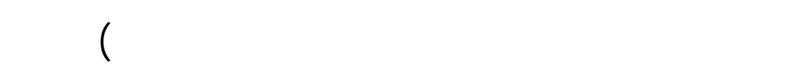
الظر عن طريقة إضافته إلى الحصول على لطاول الحوالمل

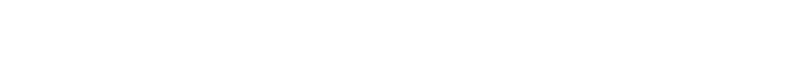

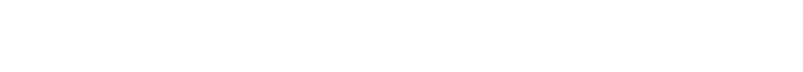

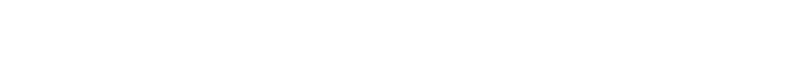

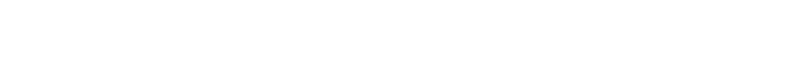

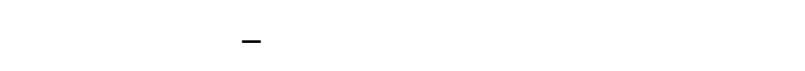

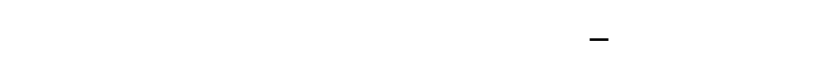

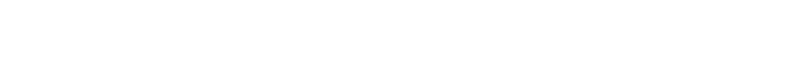

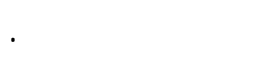

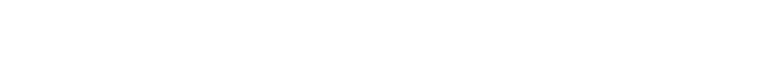

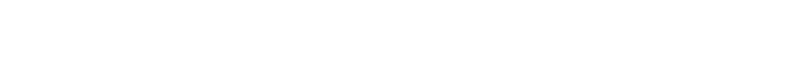

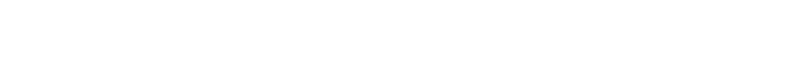

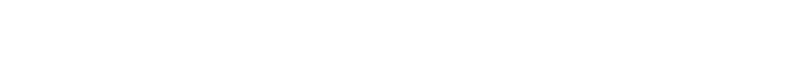

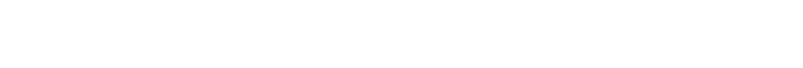

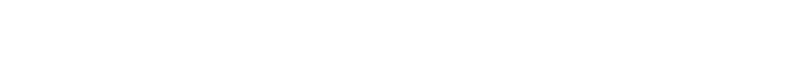

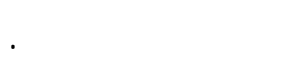

لجرى هذا البمث خلل علم 10 - r في موقعين مختلفين هما مشنل قسم الزهور ونباتات الزينة وتنسيق الحدائق بكلية الزراعة-جلمعة المسكندرية - بلالشطبق وم ششل المنت _زة

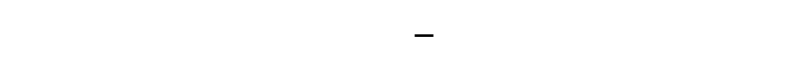

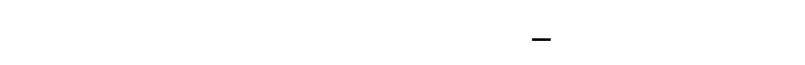

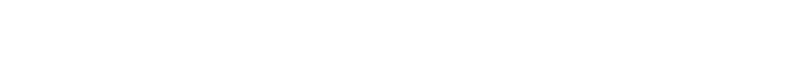

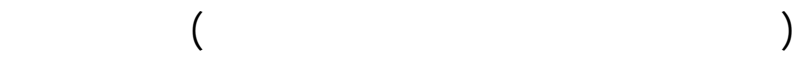

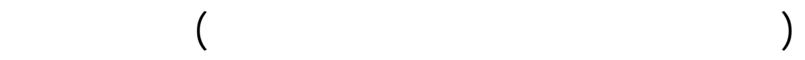

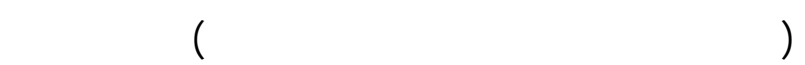

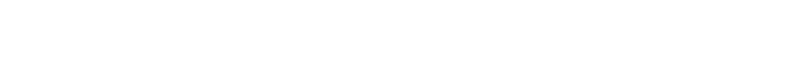

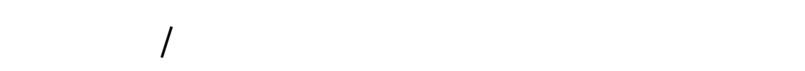

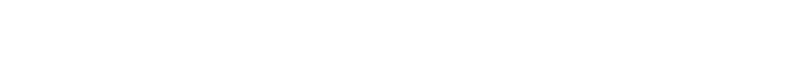

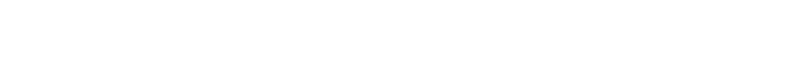

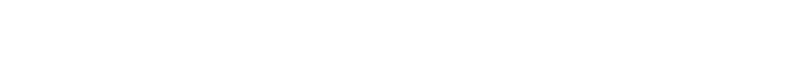

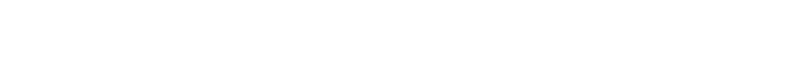

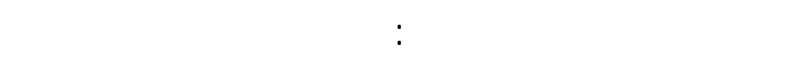

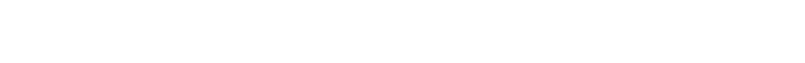
الجلاديولس .وقد صممت التجربة على هيئة قطع عثوائية كلملة حيث رتبت النبانت فى أريع مكررات وثلاثة نباتتات لكل وحة تجريبية.

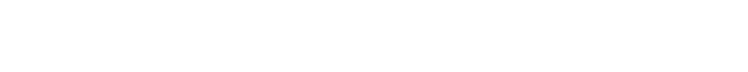

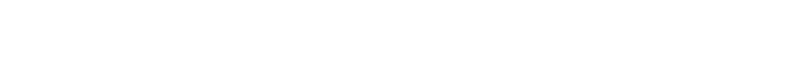

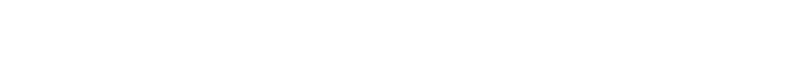

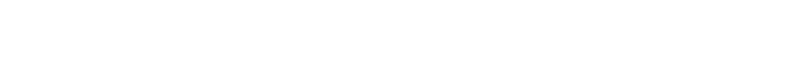
لنبت الجلاديولس(نمو خضرى وزهرى وإلتاج الكوره لت 